\title{
Infrastructure Maintenance in the Jifu Region, Beijing Metropolitan Region during the Eighteenth Century
}

\author{
Takehiko To
}

During the eighteenth century, China proper was under the rule of the Qing Dynasty founded by the Manchus at the beginning of the seventeenth century. By the middle of the eighteenth century, the Qing Dynasty had become a vast empire; it directly controlled the Manchu heartland and the eighteen inner provinces of China, and had annexed the Mongolian territories and Tibet and extended its power into Central Asia, and entered into a tribute system with Korea, Ryukyu, and Vietnam. It was also engaged in trade with Russia and Japan. Qing relationships with neighboring countries were based on a system that that reflected relative power, distance, and importance. The Qing Dynasty brought stability to East Asia through its skillful foreign policy, which was known as Pax Manchurica. ${ }^{1}$

Domestically, the Qing rulers took over the Ming bureaucratic institutions, adding on the new Board for the Administration of Outlying Regions to supervise newly incorporated territories, and establishing the Grand Council to strengthen the efficiency of the administrative structure. ${ }^{2}$

Global deflation during the "Crisis of the Seventeenth Century" affected China in the form of the Kangxi Depression (Kangxi Gujian). ${ }^{3}$ As overseas trade declined and less silver came in from abroad, the economy contracted. Once this cycle had concluded, the economy entered a new stage of prosperity, which lasted from the end of the seventeenth century to the first half of the nineteenth century. As commodity prices rose the consumption of cereal products and the production of handicraft goods and luxury products flourished. China also benefited from the long reigns of three generations of comparatively wise emperors who reigned for over 130 years - the Kangxi Emperor (1662-1722), the Yongzheng Emperor (17231735), and the Qianlong Emperor (1736-1795) - a time that came to be known as 
the golden age of the Qing. ${ }^{4}$ This period could be extended by a further forty or so years, leading up to the Opium War in 1840, and could be called the "Long Eighteenth Century of Qing Rule." ${ }_{5}$ This chapter focuses on water management practices in the Jifu (Beijing Metropolitan) Region, during the eighteenth century.

\section{GEOGRAPHIC CONDITIONS}

Beijing served as the capital of the Qing dynasty, and the region known as "Jifu," that is, the region around the capital, was known during this era as Zhili province. Jifu signifies land that is directly controlled by the emperor, while "Zhili" means "direct control." This region, which is now administratively under partly under the Beijing Metropolitan government and partly under and Hebei province, covered over three hundred thousand $\mathrm{km}^{2}$, and was roughly the size of present-day Germany. Registered land that was subject to tax levies totaled 65,719,000 mu (or approximately forty thousand $\mathrm{km}^{2}$ ) in $1753 .{ }^{6}$

The region has a warm, continental monsoon climate: winters are cold with little snow, while summers are hot with heavy rains. The average temperature is around $10^{\circ} \mathrm{C}$, and the average annual rainfall on the plains is around five hundred to six hundred meters (about a third of that received in Japan). Rain is particularly scarce during the spring, autumn, and winter, and the land is often arid.

The Jifu Region is part of the North China Macroregion described by G. William Skinner.7 A macroregion is a physiographical regional division created for natural and economic reasons by a river catchment, and differs slightly from administrative regional divisions. The Jifu Region is in the northern part of the North China Macroregion, while in the west, hilly terrain runs along a large mountain range, and alluvial plains created by the Hai River system lie in the east. The North China plains were located downstream of the Yellow River prior to the Common Era, and though they have developed since ancient times, it is likely that cotton production was only just possible in coastal areas after the tenth century, given the alkaline soil (the result of salt accumulation), which was a consequence of overdevelopment in ancient times. Grain production was insufficient to support the consumption needs of the region, and the capital population relied on grain imports from the south (through the grain tribute, or caoyun, system).$^{8}$

\section{POPULATION}

Political stability and favorable economic conditions allowed for rapid population growth. China had a population of approximately 150 million people at the beginning of the seventeenth century; by the eighteenth century this number had grown to two hundred million. It continued to grow to three hundred million by the end of the eighteenth century. ${ }^{9}$ 
Various strategies were implemented across China to cope with the increasing population. Sichuan province in the Upper Yangtze Macroregion developed its mountainous regions to cultivate New World crops like maize, sweet potatoes, and potatoes. ${ }^{10}$ The Jiangnan Region in the Lower Yangtze Macroregion, which was already an economically advanced region, developed its handicraft industries (such as cotton and silks), and continued further along the path of urbanization as a means of absorbing the growing population. Meanwhile, Fujian province in the Southeast Coast Macroregion, which in comparison was struggling economically, avoided experiencing severe population pressures when millions migrated abroad to Southeast Asia and elsewhere as overseas Chinese, or Huaqiao.

The population was also growing remarkably fast in the North China Macroregion, though this region did not have access to resources such as underdeveloped land as in the Sichuan Region or commodity production levels such as those in the Jiangnan region. Between 1580 and 1660 the region's development cycle was affected by the crises that occurred as the Ming dynasty declined, namely, famines, epidemics, rebellions, and invasions, and the confusion that resulted as power was being transferred to the Qing. The population initially peaked in 1580 at twenty-eight million, then grew sharply under the Qing to five times that size by 1850 , when it reached 120 million. ${ }^{11}$ Economic activity also peaked around this time, and Beijing's population reached approximately one million. Jifu province had to expand into previously uninhabitable areas to cultivate land for the province's growing population, which was also the main pressure behind the region's efforts to maintain infrastructure through public works.

\section{ASPECTS OF LOCAL SOCIETY}

At the beginning of the Ming dynasty (early fifteenth century) the administrative management of local societies was entrusted to self-governing organizations in rural areas known as li. However, reforms to the tax system (i.e., the introduction of the Single Whip Reform, or yitiao bianfa) at the end of the Ming dynasty (sixteenth century) changed the situation; land and corvée were combined into a single payment in silver, rather than in kind; people began paying their taxes directly to the government in silver. Authority over local society was transferred from the $l i$ to the magistrate, and the infrastructure maintenance that had previously been carried out autonomously by local social organizations became the responsibility of the magistrate. ${ }^{12}$

At the same time, the central government's control of magistrates tightened significantly, and performance evaluations were based primarily on a magistrate's ability to collect taxes and maintain order. Under Qing rule, magistrates were not permitted-under the Avoidance System-to serve in their place of birth, and in principle they were expected to change posts every two to three years. 
Under these circumstances, local elites found it necessary to negotiate with the magistrate to protect their region's interests. Composition of the elite varied in different regions: in economically developed regions like Jiangnan, retired officials. (Those who had advanced in civil service examinations to the highest status of jinshi [a graduate of the imperial examination] and juren [provincial graduates], collectively known as gentry [xiangshen], had a great deal of power.) Meanwhile in Jifu, the local elite included many lower degree holders such as sheng yuan (a student of a prefectural or county school) and jian sheng (a student of the Imperial Academy), in which case the magistrate had the most power. ${ }^{13}$ Since the region was very close to the center of national power in Beijing, government policies had a comparatively direct impact, and, in fact, the Kangxi Emperor and the Qianlong Emperor often visited the Jifu Region, thereby ensuring the concrete manifestation of their policies.

\section{CHALLENGES FACED BY THE QING DYNASTY IN THE SEVENTEENTH CENTURY}

When the Kangxi Emperor assumed direct rule in 1667 he intended to address three issues: the Three Feudatories (sanfan), the grain tribute system (caoyun), and flood control of the Yellow River (hewu). The Three Feudatories were a military and political issue related to the suppression of rebellions led by Wu Sangui, who had previously helped the Qing shore up control over China proper, while both the grain tribute system and the flood control system for the Yellow River related to infrastructure. The Jiangnan Region was the economic center of Ming and Qing China, and important industries were concentrated there, including the production of commodities such as raw cotton, the silk and cotton textile handicraft industries, and the production of salt. In addition to this concentration of wealth it was also a cultural center, producing a relatively large number of successful candidates in the imperial civil service examinations.

Beijing, however, was the capital and political center, and, as a result, various resources were transferred from the south to the north. The Grand Canal system, which extended approximately twenty-five hundred kilometers from Hangzhou to Beijing, served as a major transportation artery, and was used in the grain tribute system to transfer wealth from the south to the north: every year, four hundred thousand to five hundred thousand tons of grain were transported to Beijing from the rice bowl in the middle of the Yangtze River Basin (Huguang Region), through the Jiangnan Region. This transfer of wealth served to ensure the unity of an empire in which the politics and the economy were divided between the north and the south. When this north-south structure broke down at the end of the nineteenth century, the empire began to split apart. In other words, maintaining the Grand Canal's infrastructure played an important role in the empire's survival. 
The second major infrastructure concern is North China was related to the Yellow River; successive dynasties concentrated enormous quantities of energy in controlling the river. The Yellow River, flowing through the loess highlands of Northwest China, gathered a high sediment content, which resulted in frequent flooding. From ancient times, skill in controlling the Yellow River had served as a marker of the legitimacy of China's rulers. As a result, the scholarly officials, who in general paid little heed to technology, devoted great effort to flood control, which they frequently discussed, and about which they amassed a wealth of literature.

The Qing dynasty was no exception. The Kangxi Emperor appointed Fu Jin (1633-1692) as the director-general of River Conservation in 1677. Fu Jin developed a successful flood control program for the Yellow River, but even Jin's comprehensive plan could not prevent the continuing erosion of the river's embankments, and the Qing was forced to conduct constant maintenance. Just prior to the eighteenth century the central government paused in its nationwide focus on infrastructure maintenance and public works related to the grain tribute system and flood controls on the Yellow River, and embarked instead on redeveloping and improving the regions surrounding the capital.

\section{FLOOD CONTROL AND IRRIGATION POLICIES IN THE JIFU REGION DURING THE EIGHTEENTH CENTURY}

Some of the improvements in regions surrounding the capital included developing flood control measures for the Yong-Ding River and other rivers. Work also commenced on rice paddy development projects, albeit temporarily.

\section{Flood Control on the Yong-Ding River}

The Yongding River originates in Shanxi province, crosses over the Taihang Mountains, and passes through the Marco Polo Bridge ( $\mathrm{u} \mathrm{Gou} \mathrm{Bridge)} \mathrm{to} \mathrm{the}$ southwest of Beijing, where it joins the sea east of Tianjin. Fortified embankments had been constructed around Beijing to protect the capital during the Ming dynasty, but the river's lower reaches had been neglected, and the river, which was much like the Yellow River in that it had high sediment levels, frequently changed course, and the roads that intersected with the river were frequently damaged by floods. Local gazette records from the Late Ming era clearly described the loss of life and fortunes whenever the river flooded, but local officials only addressed the issue in a palliative manner, while suggesting that prayers be offered during religious services.

Under the Kangxi Emperor high waterworks policies were implemented by the central government on stretches of the Yongding River downstream of Beijing, and the first embankments were constructed as far as the middle basin in 1698 . It was at this time that the Kangxi Emperor gave the Yongding River its name, 


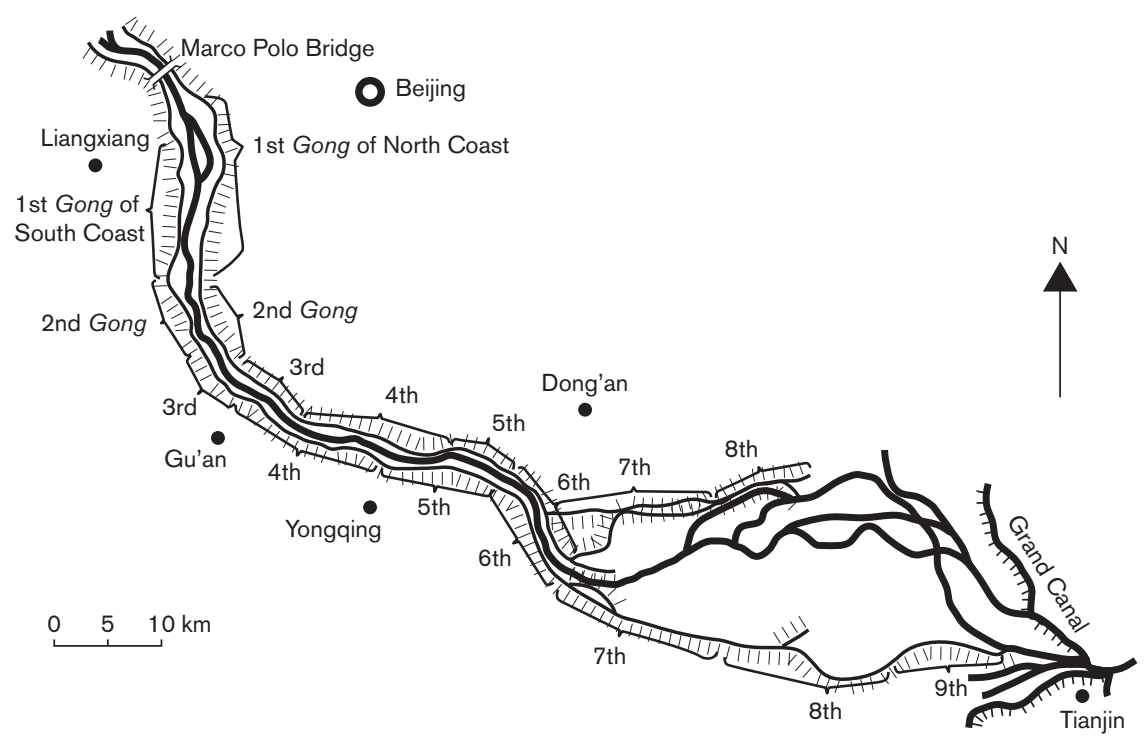

MAP 3. The Flood Control System of Yongding River

meaning "the river of eternal stability". The embankments were extended a further sixty kilometers downstream in 1700, and then to the outskirts of Tianjin in 1726. This expanded the area that could be inhabited and cultivated within the sphere of the embankments, and also made possible the cultivation of fertile soil known as $y u d i$ on the riverside land, which the government leased to farmers. Consequently both the population and productive capacity increased, though the establishment of a fixed waterway concentrated sediment deposits outside the embankments, and made it necessary to dredge the river constantly to protect the raised riverbed. Moreover, when the embankments were breached, the damage to human settlements was greater than it had been prior to this construction.

The Qing government responded to this problem by establishing jurisdictional regions of about five to fifteen kilometers known as gong on the northern and southern banks of the Yongding River to maintain its embankments, and appointed an assistant magistrate to oversee them; it also established jurisdictions known as hao every five hundred meters, and stationed soldiers to guard the embankments. (See map 3.) Ultimate overall responsibility for flood control of the Yongding River was initially given to the central government's Board of Works but was later transferred to the governor general of Zhili province. The yearly cost of the gong was between one hundred thousand to two hundred thousand taels, ${ }^{14}$ at a time when major works were being conducted for around twenty thousand taels in normal circumstances; these costs were borne entirely by the central government. (At the time, central government reserves were around twenty millon taels.) 
Approximately thirty thousand workers could be mobilized for a single project. In 1738, 190,000 taels were spent building a large stone facility like the Jinmen Sluice to act as a lock to control water volume. Three hundred dredgers (five to six meters long) and nine hundred dredge workers were usually employed in areas where downstream deposits of sediment had gathered. They dredged two to three fang (one fang is approximately 3.3 cubic meters, or approximately four to six tons) of mud per day, in five-day periods when water levels were high, from March to May and August to October. However, the operation of these dredgers ceased in 1764 .

Since maintenance costs were very high, a proposal was made by the scholar official Jiagan Sun (1683-1753) in 1740 to abandon the embankments, and instead follow a low waterworks policy of "governing without governing" that returned the river to a pre-1698 state. Jiagan Sun argued that only one or two villages would be harmed in the case of a flood, and mitigating this damage would cost only onetenth of the costs that would be incurred if the embankments burst. ${ }^{15}$ The Qianlong Emperor supported this policy and even adopted it for a time, but in the following year (1741) there was such widespread and severe flooding that it was subsequently impossible to rehabilitate the people and redevelop the area. In the flood's immediate aftermath, embankment-based flood control policies (i.e., high waterworks) were once again adopted, and they were retained until the end of the Qing.

Flood controls of the Yongding River were most effective during the early years of the Qianlong Emperor's reign. Under Guancheng Fang $(1698-1768)^{16}$ a Han official - who had held the position of governor general of Zhili from 1749 to 1768 and who had previously been successful in the disaster relief efforts of $1743^{17}-$ conducted thorough surveys of downstream sediment deposits in 1752 and 1755, and the course of the river was subsequently changed multiple times by moving embankments. These were major projects that involved moving residences, farmland, and graveyards, but they were successfully implemented according to plan.

The Qianlong Emperor had great faith in Guancheng Fang, and often met with him for face-to-face discussions unrelated to formal work-related instructions or reports. Furthermore, they occasionally communicated by exchanging poetry, which implied their real intentions, which they were unable to express in the formal official documents. This method was used when they committed to make flood control policies for the Yongding River as well. The Qianlong Emperor once asked Guancheng Fang for how many years it would be possible to maintain the river's course, to which the official replied that it could last for twenty years. However, when asked what would happen afterward, he was unable to provide an answer. ${ }^{18}$ Essentially, the river's embankments would require constant maintenance. In 1773, twenty years after Guancheng Fang first changed the course of the river, his successor Yuanli Zhou initiated the Great Works (da gong), a large-scale maintenance project that ended up being the last comprehensive work undertaken during the Qing. At its conclusion, only embankments that burst as a result of water damage were dealt with. 
The 1748 local gazetteer of Dongan County, located in the Yongding River valley basin, recorded a series of questions and answers between local elites and the local magistrate (the editor) concerning flood control of the Yongding River. ${ }^{19}$ One of the first questions expresses local dissatisfaction with flood control measures on the Yongding River, and asks if there is any basic policy for flood control of the river. The local magistrate responds that unfortunately there is no basic policy, and no way to avoid the build-up of sediment downstream, thereby making it necessary to deal with the matter on a continuing basis. This could be taken to suggest that the local magistrate is expressing responsibility for the river's maintenance.

\section{Other Rivers}

Apart from the Yongding River, four other rivers once flowed in the Jifu Region: the north canal, the south canal, Daqing River, and Ziya River. These were different from the Yongding River, in that they were used as transportation routes. For example, the Ziya River was used to transport salt produced in the Tianjin Region upstream, and was an important river for the nation's finances, because of the state's monopoly on salt at the time, which meant that the central government controlled its production and distribution. It was also an important route for commerce, as it was used to transport grains and raw cotton from upstream regions to Tianjn. This led to the serious challenge of drafting a flood control policy that would maintain the route while protecting the farmland and residences in the area around the river.

Work on embankments for the Ziya River began at about the same time as for the Yongding River in 1700, under the Kangxi Emperor's high waterworks policies. While this limited unforeseen flood damage and expanded the cultivatable and inhabitable land around the river, it also resulted in more serious damage whenever a flood occurred, and the embankments required constant maintenance, thereby necessitating the stationing of officials at strategic points along the river, albeit on a smaller scale than on the Yongding River. The ultimate authority lay with the governor general of Zhili province, as was the case as for the Yongding River.

Different flood control policies were implemented on the river during the Yongzheng and Qianlong years according to the prevailing conditions. For example, the governor general of Zhili province, Guancheng Fang, seriously altered the course of the river in 1753. However, whereas the central government bore most of the costs for the Yongding River, financial responsibility for the Ziya River lay with the regional government, and ways had to be found to cover these costs, such as by charging interest on loans from the government to pawnshops (yingyun shengxi yin). During the Qianlong era, contributions from the Tianjin salt merchants who used the river to sell their salt were used to pay for these works. Later, and in particular after 1766, Manchu officials involved in the salt trade and administration 
gradually acquired greater influence over flood control policies, and became important political actors. ${ }^{20}$

\section{Paddy Field Development Projects during the Yongzheng Era}

In addition to the infrastructure improvements that primarily focused on flood controls discussed earlier, irrigation development projects known as Jifu yingtian were also conducted during the Yongzheng era. Prince Yi (1686-1730), the younger brother of the Yongzheng Emperor, started a redevelopment project for the areas surrounding the capital in 1725 . Irrigation facilities were built, and efforts were made to develop paddy fields, in an attempt to increase the productivity of a region that was then a dryland farming area. There had previously been multiple debates over the issue, with discussions during the periods of crisis at the end of both the Yuan and Ming dynasties over whether to increase agricultural production in the Jifu Region to lessen the burden of transporting grains from the south to the north. However, the aim behind developing the region in the eighteenth century was to improve its productivity, while maintaining the grain tribute from south to north, and it may have involved the application of a type of labor-intensive rice paddy cultivation in northern China that was becoming increasingly popular in the Jiangnan province and Japan at the time.

From 1727 to 1730 a special government office (shuili yingtian $f u$ ) led by Prince Yi as its commissioner divided Zhili province into four jurisdictions to develop the rice paddies. Experienced farmers from the south were invited to provide technical guidance, while the government provided funds, and gave awards to supportive farmers. The government spent several million taels over three years to develop seven thousand qing $\left(420 \mathrm{~km}^{2}\right)$, and private citizens developed a similarsized area. Liangji Hong (1746-1809), known as the Malthus of China, made a calculation that it contributed the amount of food needed for approximately three hundred thousand more people, assuming that the amount of space needed for one person for one year was $4 m u$ (twenty-four hundred $\left.\mathrm{m}^{2}\right)^{2{ }^{21}}$

According to government records, the development project was successful for a time, but in the years following the death of Prince Yi in 1730, with few exceptions, most of the paddy fields were abandoned. Several factors, including environmental factors, were responsible. They included an unstable water supply, very hard sediment, the unsuitability of the soil for rice farming, the technological limitations of rice paddy farming in the Jifu Region, differences in eating habits between the northerners (who preferred wheat) and the southerners (who preferred rice), and resistance from local students (shengyuan) and elites (jiansheng) who feared tax hikes. Following the death of the Yongzheng Emperor in 1735, the Qianlong Emperor assumed power and immediately abolished the special government office, thereby abandoning the central government-led development of rice paddies in the Jifu Region, and instead focusing on flood control policies. 


\section{The Shapeless Treasury (Wuxing Zhi Tangcang)}

There were both successes and failures among the numerous public works projects conducted in the Jifu Region by the Qing in the eighteenth century. The phrases yigong daizhen (以工代賑) and gongzhen (工賑) (i.e., providing work to relieve poverty) were frequently employed as a way of illustrating the worthiness of the government's expenditures on these projects. This was a smart twofold method of employing citizens to work on projects that tackled disasters and paying them wages for their efforts as a form of disaster relief.

In implementing the disaster relief plans, a crucial issue was having an adequate supply of small denomination copper coins available to pay the wages of those who were hired to do such work. In contemporary China, silver was generally used for paying taxes and in larger transactions, and copper was used in everyday life. However in the Jifu Region, copper was more customarily used than silver. As the population grew, the demand for small coin denominations increased, but a fall in the imports of Japanese copper led to an insufficient copper supply, and caused problems for the government. Around 1740, the Qing government was taking three thousand tons of the copper produced each year at the copper mines in Yunnan province. It was transported on a nine-month journey down the Yangtze River and used for public works, rather than as a basis for commercial trade. It was taken north to the two mints in Beijing where up to 1.5 billion copper coins were produced each year ${ }^{22}$ that were used to pay the wages of construction workers. Wages for earthworks per day were one sheng (around one litre) of rice and eight wen (eight copper coins) for food, handling fang (approximately $3.3 \mathrm{~m}^{3}$, four to six tons) of soil. This meant that a large number of copper coins were kept in stock in the Jifu Region for currency, which contributed to growth in the region's economy. However, yigong daizhen ultimately remained a countermeasure against disasters, and its critics pointed to its inefficiencies.

In 1744 , the censor Chao-sheng Zhai ${ }^{23}$ became concerned about the policies being implemented to deal with that year's water damage. He therefore went to see the emperor, who was a passionate advocate of the need for irrigation projects in Jifu, to emphasize the serious inefficiency of yigong daizhen, and to argue that the civil service should mediate these policies. He argued that instead of paying out large sums of money in relief when a disaster occurred, it would be better to plan irrigation projects in advance, and invest in public works to provide irrigation facilities that would provide "relief that is not abused" (wubi zhi zhenxu 無 弊之賑恤). Moreover, he argued that instead of stockpiling grain to counteract increases in the price of rice, the government should instead build rice paddies to improve the harvest and so create "never-emptying granaries" (bujie zhi changing 不竭之常平). He also argued that instead of providing incentives for wealthy citizens in the capital, the government should revive work on irrigation projects to create a “shapeless treasury" (wuxing zhi tangcang 無形之帑蔵). ${ }^{24}$ This specific 
term symbolized his argument that developing arable land would have the same effect on coping with famine and poverty as maintaining a treasury or granaries for poor and famine relief. In other words, the term "shapeless treasury" or "neveremptying granaries" in those days implied the sense of "social infrastructure" in a contemporary meaning.

These propositions were an attempt to go beyond the traditional methods based on "famine relief" (huangzheng), and by extension yigong daizhen, that had been used in the past to temporarily deal with disasters and famines. In other words, the Qing should put all its efforts into improving its infrastructure (such as maintaining embankments, improving irrigation facilities, and promoting the cultivation of paddy rice) to improve productive capacity and increase peoples' welfare.

These ideas were disseminated among the administrative organs at each level of the Qing, and resulted in the implementation of various construction projects funded by government finances at both the central and the regional levels in the eighteenth century. They were subsequently also maintained. For example, data from Ningbo, Zhejiang province, shows that water damage clearly lessened between 1751 and 1800 , during the reign of the Qianlong Emperor. This information provides one measure of the efficacy of the Qing's infrastructure improvements. ${ }^{25}$

In June 1801 , heavy rains caused widespread water damage in the Jifu Region, leading the Jiaqing Emperor (1796-1820) to expend large sums for gongzhen. This achievement was proudly recorded by the Qing in the Chronicle of Public Works and Relief Activities (Qinding Xinyou Gongzhen Jishi), but, in reality, the power of the central government to carry out the improvements of social infrastructures ebbed during the nineteenth century, and this act illustrates that the government was now limited to implementing temporary relief measures through gongzhen.

\section{OTHER PUBLIC WORKS IN THE JIFU PROVINCE DURING THE EIGHTEENTH CENTURY}

Various other public works were implemented by the central government in the Jifu Region during the prosperous eighteenth century, as it tried to strengthen social infrastructure and absorb the growing population. These initiatives included Guancheng Fang's decision to build a public granary to hold the fruits of the flood control of the Yongding River ${ }^{26}$ the establishment of a foundling home, ${ }^{27}$ relief work for the poor, and the promotion of cotton cultivation. ${ }^{28}$

"Famine relief" (huangzheng)_ a custom of providing temporary relief at times of disaster-had existed in China since the time of the ancient emperors, as had flood control projects for the Yong-Ding River and flood control of the Yellow River. There was therefore a close relationship between these traditions and the traditional civil service, and they continued to be practiced at least to some extent until the end of the dynasty. However, several things did not continue: the development 
of rice paddies, which were ill-suited to the soil and land conditions and required the constant toil of farmers; the public granary, managed autonomously by local power holders; and the foundling homes, based in Buddhist temples. The government's attempt to uplift all sections of society across the region did not last, and private society in the Jifu Region lacked the power to support these efforts by itself. Meanwhile, self-government in Jiangnan was left to the local elite class, of which the Benevolent Societies (shanhui) and Benevolent Halls (shantang) are examples. ${ }^{29}$

In the early years of the Qianlong Emperor Zhili province was developing its "shapeless treasury," or, in other words, improving its social infrastructure and the region's redevelopment. At the same time, it was guarded by a systematic framework structured by the strong leadership of the emperor, intelligent agenda-setting by the governor general and governor, an embankment maintenance management system funded through focused public investment (which led to an expansion in inhabitable and cultivatable land), and success in absorbing the growing population. Flood control and irrigation projects also served to guarantee employment. The wellthought-out yigong daizhen policy, which involved flood control and minting vast quantities of copper coins in Beijing, based on an effective transportation system for moving copper from Yunnan, helped the region transition to a currency-based society, which in turn played an important part in stimulating the province's economy. The favorable economic conditions of the time made these policies possible, and the redistribution of wealth that occurred under these conditions allowed the Qing's authority and sovereignty to impact each member of society in a rather striking way, by stabilizing society and arguably creating a form of commonality.

Qing authority waned as it entered the nineteenth century, and it became difficult for the regional government to carry out public works in the Jiangnan region. Consequently the further implementation of these works was increasingly left up to the local elite. The responsibility for public works in northern China shifted from the central and provincial governments to local magistrates at the county level, but a lack of funds and an inability to oppose the influence of Manchu officials meant infrastructure improvements became patchy.

Under the favorable conditions of a strong economy, population growth, and the authority of wise rulers, eighteenth-century China (albeit limited to the regions around the capital) made several attempts to transcend the framework of a limited government, which had been based on the tax collection contract, minimal maintenance of public order, and the distribution of benevolent relief when disaster struck, through being engaged in the improvement of the social infrastructure that might deserve the concept of welfare state. However, limits to governance, coupled with the technological and social limits characteristic of the time, made it impossible for this new state to continue. As China entered the nineteenth century, the favorable conditions it had enjoyed in the eighteenth century were no longer 
present, and responsibilities for developing and maintaining infrastructure were decentralized, according to the conditions in each region.

\section{NOTES}

1. See Mancall 1984.

2. See Bartlett 1991.

3. Kishimoto-Nakayama 1984.

4. For research summarizing eighteenth-century China from a comprehensive political, cultural, economic, and regional perspective, see Naquin and Rawski 1987.

5. See Ni 2013.

6. Wang 1973.

7. Skinner 1985 .

8. See Chi 1936.

9. Ho 1959.

10. See Perkins 1969.

11. See Huang 1985.

12. See Ch'u 1962.

13. See Ho 1962.

14. 1 tael was worth $37.301 \mathrm{~g}$ of silver according to the official standard (ku-ping liang) for the collection of tax.

15. Sun, Jiagan, Sun Wen Ding Gong Zoushu (Collected Memorials of Sun Jiagan), 7, ca. 1800.

16. Both his grandfather and father were exiled during the Literary Inquisition, so he was unable to join the government school during his youth or to earn a high grade in the civil service examinations, but he was raised in the home of a scholarly official, and therefore had a good education, and was a famous poet.

17. See Will 1990.

18. Hong Li, (Qian-long Emperor), Yuzhishi Siji (Forth Collection of Qianlong's poems), 59, 1782.

19. Dong'an xian zhi (Gazetteer of Dong'an County), 15, 1750. Other questions included "Would it be possible to try and wash away the sediment build-up in cloudy rivers where it is prevalent using rivers with little sediment?" "Are there not unnecessary officials stationed here?" "Would it be possible to install a sluice gate on both banks of the Yongding River to irrigate it?" "Why do some people want the government to buy out the land where it floods downstream, and some who do not?"

20. See To 2011.

21. Hong, Liang-ji, Juan Shi Ge Wen Jia Ji (Collected Essays from the Juan-shi Hall), 1, 1795 .

22. The value of this in silver at the time was approximately 1.2 million taels.

23. The Censor was an official of low rank, but had the sole right to ask the emperor about individual political problems.

24. Pan, Xi'en, Jifu Shuili Sian (Four Collected Records on the Investment in Beijing Metropolitan Region), 3, 1823 .

25. Oka 2012.

26. Fang, Guancheng, Ji-fu Yicang Tu (Maps of the Public Granary in Zhili Province), 1753. According to these maps, 1,005 public granaries were built in 144 counties in Zhili province, for which detailed management plans were drawn up and self-managed by the villages. However, they were largely disused after several decades.

27. See Li 2007.

28. Fang, Guancheng, Mian Hua Tu (Pictures of Raw Cotton), 1765. Sixteen drawings were made beginning with the cultivation of raw cotton, and ending with the production of cotton textiles, with 
explanations by Guan-cheng Fang added. The Qianlong Emperor has attached a poem to the complete works.

29. See Fuma 1997.

\section{REFERENCES}

Bartlett, Beatrice S. (1991). Monarchs and Ministers: The Grand Council in Mid-Ching China, 1723-1820. Berkeley, University of California Press.

Chi, Chao-ting (1936). Key Economic Areas in Chinese History: As Revealed in the Development of Public Works for Water-Control. London, George Allen and Unwin.

Ch'u, T'ung-tsu (1962). Local Government in China under the Ching. Cambridge, MA, Harvard University Press.

Fuma, Susumu (1997). Chūgoku Zenkai Zendōshi Kenkyū (A Study of Benevolent Societies and Benevolent Halls in China). Kyoto, Dōhōsha.

Ho, Ping-ti (1959). Studies on the Population of China, 1368-1953. Cambridge, MA, Harvard University Press.

- - (1962). The Ladder of Success in Imperial China, Aspects of Social Mobility, 1368-1911. New York, Columbia University Press.

Huang, Philip C.C. (1985). The Peasant Economy and Social Change in North China. Stanford, Stanford University Press.

Kishimoto-Nakayama, Mio (1984). “The Kangsi Depression and Early Qing Local Markets.” Modern China 10 (2): 227-256.

Li, Lillian M. (2007). Fighting Famine in North China: State, Market, and Environmental Decline, 169os-199os. Stanford, Stanford University Press.

Mancall, Mark (1984). China at the Center: 300 Years of Foreign Policy. New York, Free Press.

Naquin, Susan, and Evelyn S. Rawski (1987). Chinese Society in the Eighteenth Century. New Haven, Yale University Press.

$\mathrm{Ni}$, Yuping (2013), Research on Finance and Society in the Jiaqing and Daoguang Reigns of the Qing Dynasty. Beijing, Commercial Press.

Oka, Motoji (2012). Sōdai Enkai Chiiki Shakaishi Kenkyū: Network to Chiikibunka (Study on the Social History of Coastal Regions during the Song Dynasty). Tokyo, Kyūko Shoin.

Perkins, Dwight H. (1969). Agricultural Development in China, 1368-1968. Chicago, Aldine.

Skinner, G. William (1985). "Presidential Address: The Structure of Chinese History." Journal of Asian Studies 44 (2): 271-292.

To, Takehiko (2011). Shindai Keizaiseisakushi no Kenkyū (The History of Economic Policy in the Qing Dynasty). Tokyo, Kyūko Shoin.

Wang, Yeh-chien (1973). Land Taxation in Imperial China, 1750-1911. Cambridge, MA, Harvard University Press.

Will, Pierre-Etienne (1990). Bureaucracy and Famine in Eighteenth-Century China. Translated by Elborg Forster. Stanford, Stanford University Press. 